\title{
Mechanical tests on Corymbia citriodora battenboard panels coated and reinforced with giant bamboo veneers ${ }^{1}$
}

\author{
Fabiano Ostapiv ${ }^{2}$
}

\section{ABSTRACT}

Dense wood batten panels usually break in the glue line when loaded. This study demonstrates that thin veneers obtained from mature culms of Dendrocalamus asper by mechanical grinding are suitable for coating and reinforcing solid processed eucalyptus wood and eucalyptus batten panels. Tensile and bending tests were carried out on Corymbia citriodora timber and edge glued batten panels, with and without bamboo veneer reinforcement. The tensile test results showed that the bamboo veneers glued onto the wood and edge glued batten panels specimens acted as a mechanical reinforcement for both cases, when submitted to tensile forces parallel to the bamboo fibers. In bending tests, the edge glued batten panels specimens were tested transversally to the glue line, direction in which the panel showed the lowest mechanical resistance. The edge glued batten panels specimens without reinforcement with laminated bamboo exhibited a fragile behavior and ruptured abruptly along the glue line. A significant increase in the mechanical strength of the set was observed for the edge glued batten panels coated with laminated bamboo. In addition, the mechanical behavior changed in reinforced specimens, which ruptured slowly and gradually in the bending tests.

KEYWORDS: Dendrocalamus asper, coated wood, edge glued panels, laminated bamboo.

\section{INTRODUCTION}

Bamboo is an important building material in modern engineering (Dunkelberg 1992) and bamboo culms and shoots have a vast potential in the development of economically and environmentally sustainable enterprises and supply chains (Hsiung 1987).

According to Salamon (2009), the limited use of bamboo in the Brazilian industry is largely due to the lack of sufficient raw material and knowledge

\section{RESUMO}

Ensaios mecânicos de painéis sarrafeados de Corymbia citriodora revestidos e reforçados com lâminas torneadas de bambu gigante

Painéis sarrafeados de madeira densa geralmente rompem na linha de cola, ao serem carregados. Objetivou-se mostrar que lâminas finas obtidas de colmos maduros de Dendrocalamus asper, por meio de torneamento mecânico, são apropriadas para revestir e reforçar tanto a madeira de eucalipto processada, com pequenas espessuras, como painéis sarrafeados de eucalipto. Foram feitos ensaios de tração e flexão em madeira e painéis sarrafeados de Corymbia citriodora, com e sem reforço de bambu laminado. Os testes de tração mostraram que os laminados de bambu colados na madeira e nos painéis sarrafeados funcionaram como reforços mecânicos em ambos os casos, quando submetidos a forças de tração paralela às fibras das lâminas de bambu. No ensaio de flexão, os corpos de prova dos painéis sarrafeados foram testados na direção transversal à linha de cola, direção na qual o painel mostrou a menor resistência mecânica. Os corpos de prova do painel sarrafeado sem reforço com bambu laminado mostraram comportamento frágil e romperam abruptamente na linha de cola. Nos corpos de prova de painéis sarrafeados revestidos com lâminas de bambu, houve aumento significativo na resistência mecânica do conjunto. Além disso, houve mudança no comportamento dos corpos de prova reforçados, cuja ruptura ocorreu de forma lenta e gradual nos testes de flexão.

PALAVRAS-CHAVE: Dendrocalamus asper, madeira revestida, painéis sarrafeados colados, bambu laminado.

regarding bamboo manufacturing processes, as well as safe and efficient equipment.

In most cases, natural bamboo culms do not meet industrial requirements and need to be standardized (Yu 2007). As reported by Zang et al. (2002), in order to standardize the lignocellulosic material from bamboo culms, the culm must be processed into smaller units, such as veneers or chips, which can be used to obtain different industrial panels by applying adhesive and pressing. Moizés (2007) showed four basic types of standard industrial 
materials derived from bamboo culms, which form the basis for the production and classification of bamboo panels: veneers, slivers, strips and particles.

Eucalyptus is renowned worldwide as a raw material for various industrial applications; however, eucalyptus timber accumulates internal tension during growth, which can be released when the material is sawed. In order to avoid defects, technologies must be used to obtain sawn eucalyptus pieces, especially as a structural element or component for furniture (Vidaurre et al. 2007).

According to Gonçalves (2000), products with smaller dimensions, such as battens, allow a wider and better use of the tailings produced by the timber industry, thus reducing waste and rationalizing the lumber production process.

The development of dimensionally stable eucalyptus edge glued batten panels bonded with cold adhesive poly vinyl acetate should attract the interest of small wood processing enterprises, such as furniture makers. If this product proves to be technically feasible, several small companies can produce their own wood panels, thereby reducing the cost and scarcity of sawed wood in Brazil (Gonçalves 2000).

Salamon (2009) demonstrated the technical feasibility of using centerless grinding on a lathe to produce continuous giant bamboo veneers with 1,200 $\mathrm{mm}$ wide, 2,000 $\mathrm{mm}$ long and $1 \mathrm{~mm}$ thick, as shown in Figure 1.

These veneers can be used to manufacture a number of innovative high-value products, exploiting the characteristics of bamboo as a graded composite. Amada et al. 1996, Ghavami et al. 2003 and Ostapiv et al. 2010 described bamboo timber as a functionally graded material, which exhibits a continuous gradient

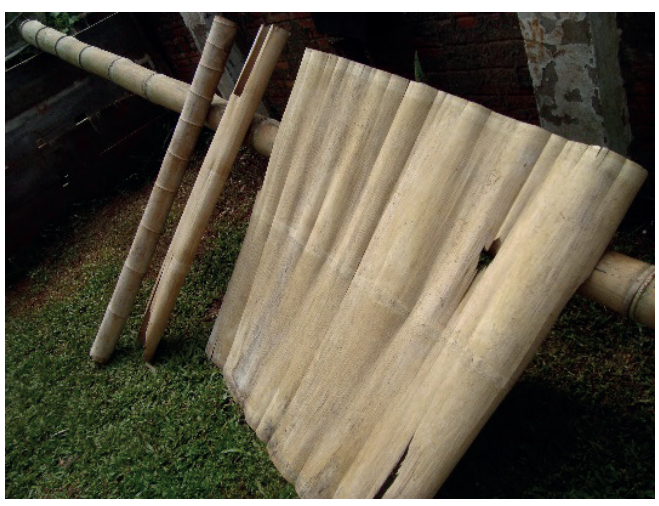

Figure 1. Dendrocalamus asper veneers obtained by centerless grinding (Source: Ostapiv 2011). of variation in its physical and mechanical properties linked to a gradual change in the size and distribution of meso and micro-structural components.

Bamboo veneers obtained by grinding on a lathe exhibit characteristics different from those produced by slicing panels made from recomposed bamboo strips (Salamon 2009). Turn lamination of bamboo culms is a significantly more productive and efficient manufacturing process, when compared to obtaining veneers by cutting solid bamboo wood longitudinally using saws or knives. The grinding process produces thin, wide and continuous high-density bamboo veneers with a good mechanical performance.

Wood laths are glued together to form the socalled edge glued panel (EGP), using small pieces of wood to obtain panels that are similar to solid wood, thus creating high-value final products. Iwakiri (2003) and Lahr \& Christoforo (2013) described this technique as efficient and sustainable. EGP is widely used to manufacture furniture, doors, flooring and roofing, as well as in construction. Figure 2 depicts Corymbia citriodora edge glued batten panels.

This study focuses on normal tensile testing of high-density eucalyptus wood and static bending of eucalyptus EGP, coated or not with giant bamboo veneers obtained by grinding on a lathe. The aim is to verify the hypothesis of mechanical reinforcement, i.e., whether coating soil eucalyptus wood and panels with giant bamboo veneers provides a significant mechanical reinforcement.

\section{MATERIAL AND METHODS}

The panels produced in this study used two renewable materials, namely Corymbia citriodora laths

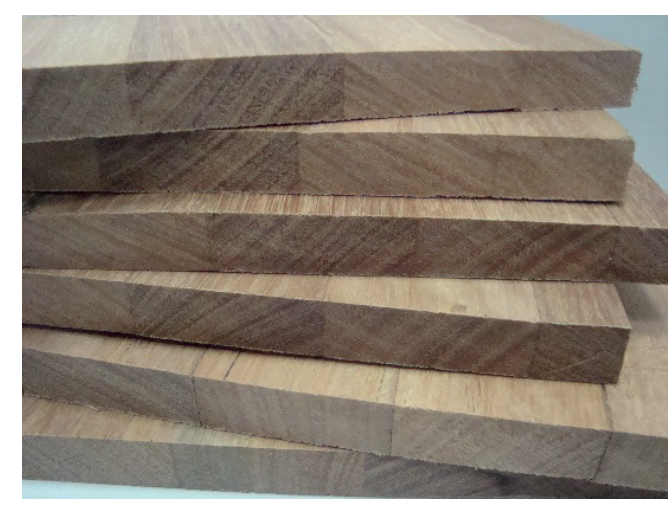

Figure 2. Experimental Corymbia citriodora edge glued panel (Source: Ostapiv 2011). 
and thin veneers of giant bamboo (Dendrocalamus asper). The final product, a Corymbia citriodora EGP coated and reinforced with bamboo veneers, is a new type of board known as battenboard or blockboard panel (Figure 3). These laminated panels are a technological evolution, in relation to EGP, since they display a unique and improved mechanical behavior, in addition to increasing the economic and esthetic value of engineered wood.

The normal tensile tests on eucalyptus wood and along the glue lines of eucalyptus laths, as well as the static bending of the panels, were conducted in a universal machine for destructive mechanical tests at the Universidade Estadual Paulista, in Itapeva, São Paulo state, Brazil, in November 2010. The materials described below were used to prepare the specimens (eucalyptus panels coated or not with bamboo veneer) for the tensile testing and those for static bending derived from these panels:

a) Corymbia citriodora eucalyptus raw material: the wood used had a high average density $\left(0.96 \mathrm{~g} \mathrm{~cm}^{-3}\right)$ and $12.5 \%$ of moisture content, and was supplied by a wood industry in Bauru, São Paulo state. The tested specimens were obtained from trees over 25 years old and $60 \mathrm{~cm}$ in diameter at the base. All the sawn eucalyptus battens were obtained from the heartwood;

b) Dendrocalamus asper bamboo raw material: the 4-year-old culms used had an average density of $613 \mathrm{~kg} \mathrm{~m}^{-3}$ and diameter of more than $170 \mathrm{~mm}$ at the base. The bamboo veneers were obtained by grinding (Salamon 2009);

c) Wonderbond 2555 polyvinyl acetate adhesive: supplied by Hexion, the poly vinyl acetate adhesive used had a good adhesion, met the DIN EN-204 European standard (ECS 2001) and had a

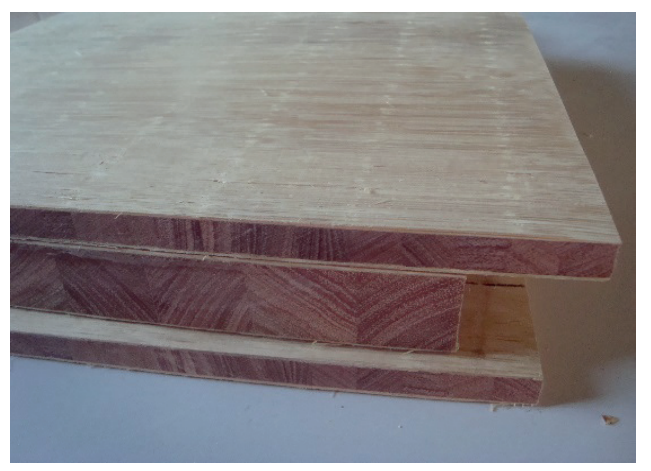

Figure 3. Experimental panels of eucalyptus laths coated with bamboo veneer (Source: Ostapiv 2011).
D3 level of moisture resistance. This adhesive is among the least expensive ones for use on wood and is widely used, particularly for indoor applications.

The eucalyptus wood specimens used for the normal tensile and glue line tests measured $33 \mathrm{~mm} x$ $64 \mathrm{~mm}$ x $50 \mathrm{~mm}$, with two 1-inch holes $25 \mathrm{~mm}$ apart (Figure 4).

The specimens were prepared according to the NBR 7190 (ABNT 1997) and tested with and without reinforcement, using double-sided $1 \mathrm{~mm}$ thick bamboo veneers.

To obtain the specimens for the glue line tests, two eucalyptus battens were glued along the centerline (rupture line) of the specimens, which were then reinforced or not in the transverse direction to these rupture lines (Figure 4).

Figure 5 shows a eucalyptus EGP and a eucalyptus battenboard panel coated with bamboo

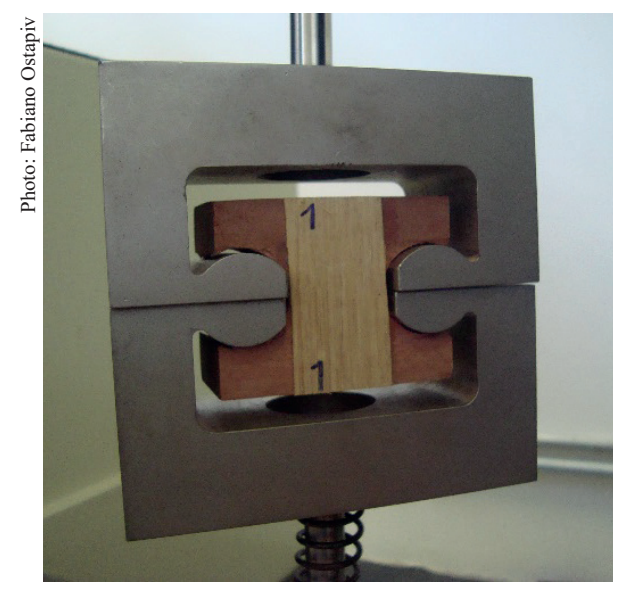

Figure 4. Corymbia citriodora wood specimens reinforced with giant bamboo veneers in the device and ready for testing.

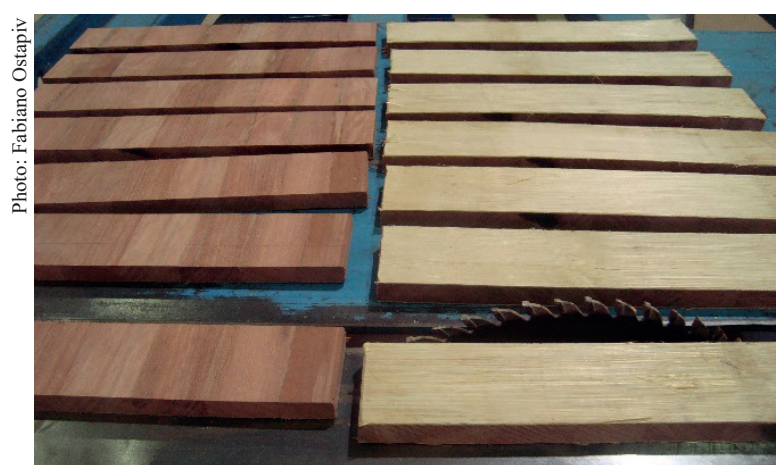

Figure 5. Specimens of Corymbia citriodora edge glued panel and edge glued panel reinforced with bamboo veneers. 
veneers. The battenboard panels were produced using two different lignocellulosic materials, eucalyptus laths, bamboo veneers and glue.

The specimens obtained from the eucalyptus EGP were sawn to dimensions of $50 \mathrm{~mm} \times 330 \mathrm{~mm}$ x $12 \mathrm{~mm}$, and those from the battenboard panel measured $50 \mathrm{~mm} \times 330 \mathrm{~mm} \times 14 \mathrm{~mm}$, according to the EN-310 European standard (ECS 2000). Twelve specimens were obtained from each panel for static bending.

The following steps were applied to verify the hypothesis of mechanical reinforcement for the normal tensile testing of eucalyptus wood coated with thin bamboo veneers: 1) prepare specimens obtained from high-density eucalyptus beams; 2) perform tensile tests on 12 normal eucalyptus wood specimens with a radial arrangement of growth rings in the region of rupture; 3 ) coat 12 eucalyptus specimens with laminas of giant bamboo on two opposite sides. The veneers were glued in the direction of the highest expected mechanical strength; 4) repeat tests.

The conducted tests followed the European standard (ECS 2000) guidelines, which stipulate the method for determining the modulus of elasticity in the bending and axial bending strength of woodbased panels with a nominal thickness greater than or equal to $3 \mathrm{~mm}$. In order to determine the modulus of elasticity, the testing machine applies force to the middle specimens, which are rested on two roller supports (Figure 6).

Twelve EGP specimens were submitted to static bending tests, followed by additional 12 specimens reinforced with bamboo veneers, which

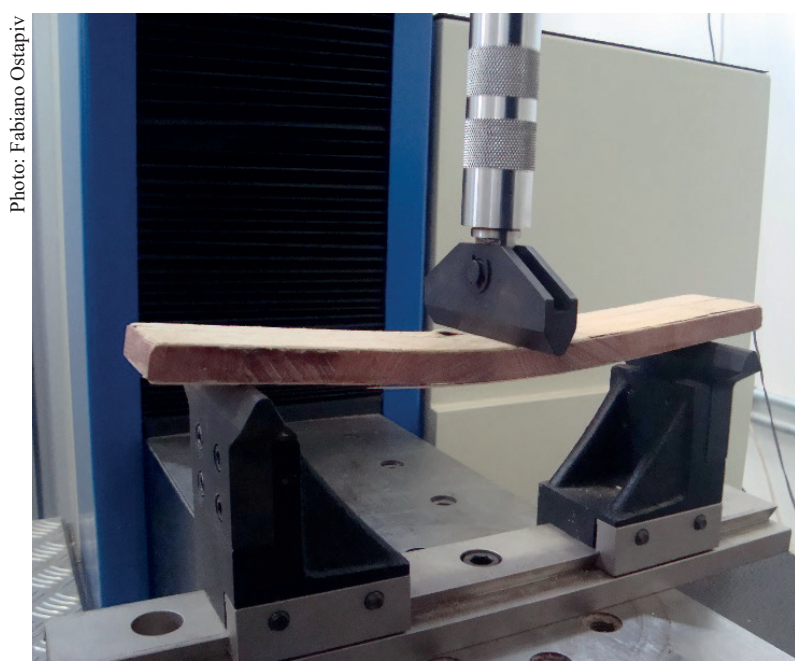

Figure 6. Bending test on bamboo battenboard specimen. were glued so that the bamboo fiber bundles were perpendicular to the glue line of the eucalyptus panels.

The mass and volume of the eucalyptus wood specimens and giant bamboo veneers were measured to calculate their density. Mass was determined on an electronic scale with precision of $0.1 \mathrm{~g}$ and specimen dimensions were measured using a pachymeter with $0.1 \mathrm{~mm}$ of sensitivity.

\section{RESULTS AND DISCUSSION}

The final average density measured for eucalyptus wood specimens $\left(980 \mathrm{~kg} \mathrm{~m}^{-3}\right)$ characterizes them as a high density material, with a density distribution evident in the low coefficient of variation $(5.8 \%)$ and standard deviation $\left(56.3 \mathrm{~kg} \mathrm{~m}^{-3}\right)$.

The bamboo strips exhibited a lower average density $\left(613 \mathrm{~kg} \mathrm{~m}^{-3}\right)$, but a higher distribution of density values, indicated by the coefficient of variation $(15.3 \%)$ and standard deviation $\left(94.2 \mathrm{~kg} \mathrm{~m}^{-3}\right)$. Figure 7 shows the distribution of density values for eucalyptus wood specimens and giant bamboo veneers.

The greater variation in the bamboo veneer density can be explained by the functionally graded material structure along the bamboo culm wall. Veneers obtained from the outer culm showed a higher density, because this region contains the highest concentration of fiber bundles, when compared to veneers derived from the inner culm.

The normal tensile testing indicated that thin eucalyptus panels are mechanically reinforced when coated with giant bamboo veneers, increasing the tensile strength of the material by an average of

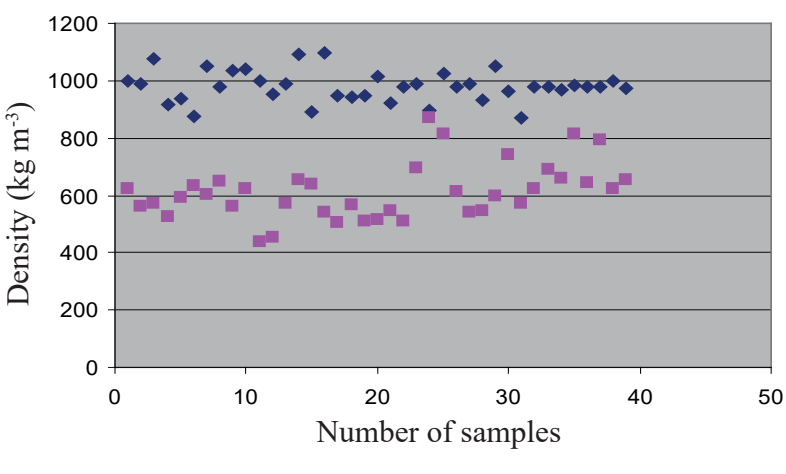

- Corymbia citriodora - Dendrocalamus asper

Figure 7. Density of Corymbia citriodora wood specimens and giant bamboo veneers. 
$50 \%$. Figure 8 shows the strength and deformation behavior of each specimen.

The eucalyptus specimens coated or not with bamboo veneers showed a similar response to the tensile test, with elastic behavior and straight lines in both graphs.

The EGP specimens were tested with and without bamboo veneer reinforcement. Figure 9 depicts the behavior of the tested specimens submitted to normal tension perpendicular to the glue line. The veneers were arranged in the direction of the highest mechanical reinforcement expected for the battenboard panel, i.e., perpendicular to the glue line, since the bamboo fibers were only subjected to parallel traction.

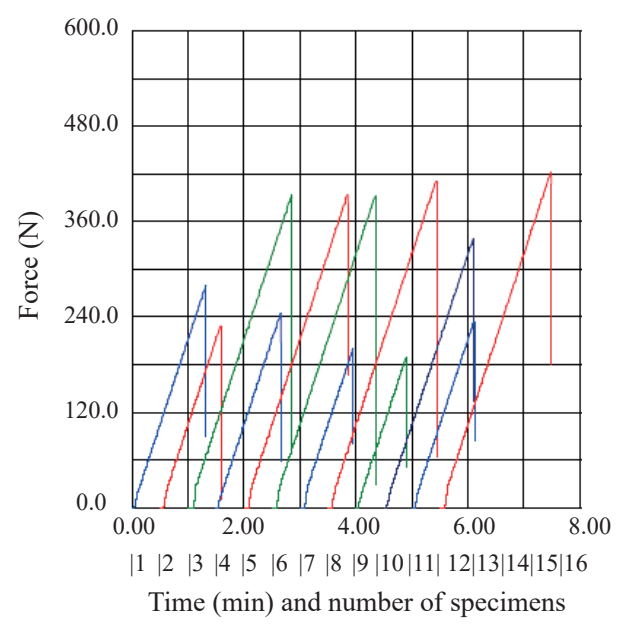

(a)
In general, the EGP specimens displayed a mechanical strength similar to solid wood, in the longitudinal direction. However, this did not occur in the transverse direction along the edges of the glued laths. In this direction, the mechanical strength of the panel is determined by the strength of the glue lines.

The mechanical strength was higher when both sides of the EGP were coated with giant bamboo veneers, with a significant increase in the transverse direction. Figure 10 shows the strength, stress and deformation of the specimens.

The mechanical reinforcement changed the behavior of the fragile rupture in the static bending of the panel, making it more elastic, ductile and reliable to use. The test results demonstrated a mechanical

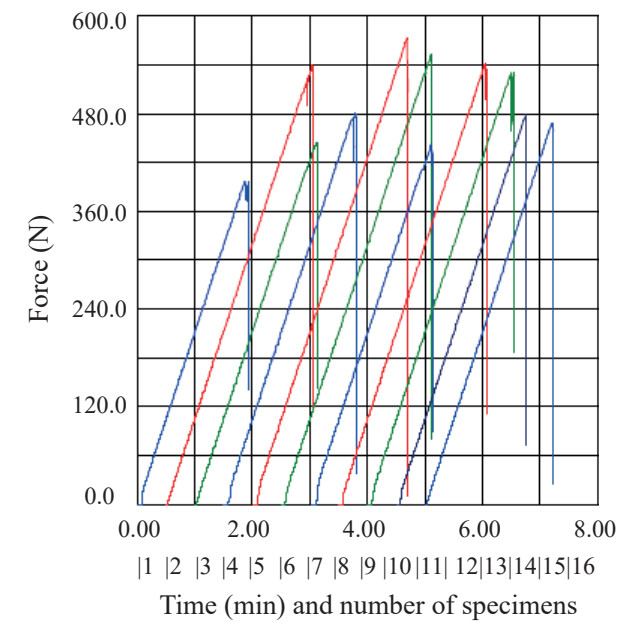

Figure 8. Normal tensile strength of eucalyptus specimens: a) uncoated; b) coated on both sides with giant bamboo veneers.

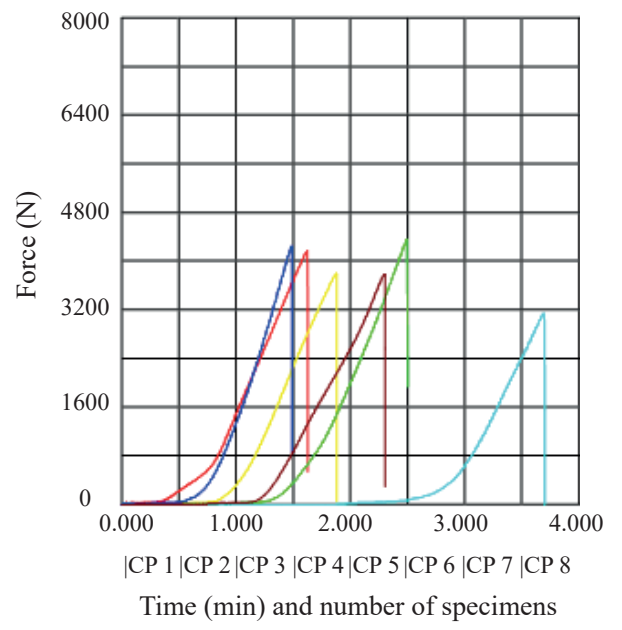

(a)

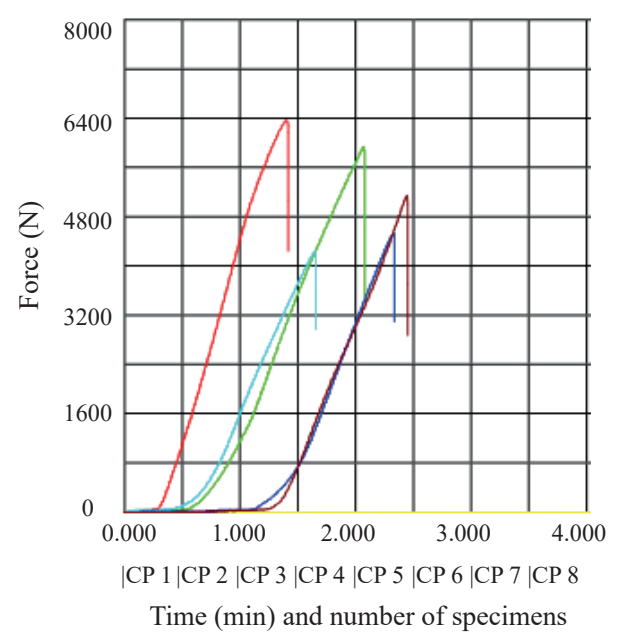

(b)

Figure 9. Normal tensile strength of glued eucalyptus laths: a) uncoated specimens; b) specimens coated on both sides with giant bamboo veneers. 


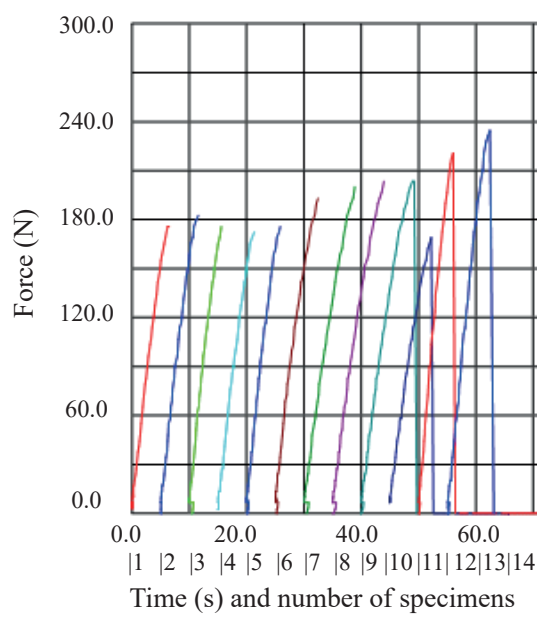

(a)

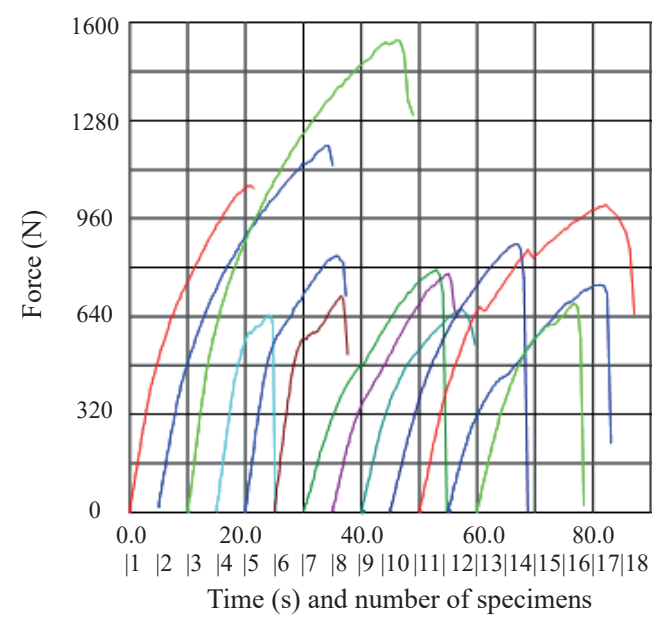

(b)

Figure 10. Bending strength of specimens tested in the transverse direction: a) eucalyptus edge glued panel with fragile fracture; b) bamboo veneer-reinforced edge glued panel with ductile fracture.

reinforcement of $336 \%$ and a $1,002 \%$ increase in the modulus of elasticity.

Most of the EGP panels without veneer reinforcement ruptured abruptly along the glue line and exhibited a lower mechanical strength (Figure 10a).

The results indicated that specimens with bamboo veneer reinforcement on both sides showed a superior mechanical performance than that observed by CortezBarbosa et al. (2017), who used glued Dendrocalamus asper strips to reinforce MDF panels and obtained a $130 \%$ increase in the modulus of elasticity.

The shape of the loading curve changed from a straight line in non-reinforced panels, indicating an elastic behavior (Figure 10a), to a curve, demonstrating a plastic behavior for the bamboo veneer-reinforced panels (Figure 10b). The average mechanical reinforcement achieved in this case was $336 \%$ higher than the results found for the nonreinforced battenboard panels.

The panels with glued bamboo veneers displayed a behavior typical of ductile materials, a desirable characteristic in structural panels. Ideally, panels should not break abruptly when mechanically loaded. The bamboo veneer was largely responsible for this change in the panel performance. Bamboo veneer serves as a fiber reinforcement on a fragile base, which is the case of eucalyptus EGP in the transverse direction of the panel.

As reported by Lee et al. (1997), the use of bamboo reinforcement improves the mechanical characteristics of non-hardwood with a density of less than $500 \mathrm{~kg} \mathrm{~m}^{-3}$. However, in the present study, it was also observed that thin bamboo veneers reinforced the high-density eucalyptus wood for the normal tensile test. Moreover, bamboo veneers glued onto EGP reinforced these panels primarily in the transverse direction (Table 1).

The use of bamboo veneers as a mechanical reinforcement was effective for both eucalyptus wood specimens and EGP.

The panels of eucalyptus laths coated with fine bamboo veneers provided a significant mechanical reinforcement and modified the behavior at rupture

Table 1. Overview of the mechanical test results obtained for eucalyptus specimens and edge glued panel reinforced with giant bamboo veneers (average values).

\begin{tabular}{|c|c|c|c|}
\hline \multirow{3}{*}{ Type of test } & \multicolumn{2}{|c|}{ Mechanical property } & \multirow{2}{*}{$\begin{array}{l}\text { Mechanical } \\
\text { reinforcement }\end{array}$} \\
\hline & $\begin{array}{l}\text { Tensile strength } \\
\text { without bamboo veneer }\end{array}$ & $\begin{array}{l}\text { Tensile strength } \\
\text { with bamboo veneer }\end{array}$ & \\
\hline & \multicolumn{2}{|c|}{$-\mathrm{MPa}$} & $\%$ \\
\hline Normal stress on eucalyptus wood & 3.6 & 5.5 & 50 \\
\hline Normal stress on the battenboard panel glue line & 4.6 & 6.0 & 30 \\
\hline Static bending of edge glued panel in the transverse direction & 9.6 & 32.2 & 336 \\
\hline Modulus of elasticity & $1,960.0$ & $19,650.0$ & 1,002 \\
\hline
\end{tabular}


by allowing the panel to bend, making it more elastic, ductile and reliable.

The use of veneers obtained by grinding bamboo culms in a lathe produced a new class of laminated bamboo panel in Brazil, known as battenboard bamboo and wood panels. These reinforced panels could have a range of possible applications, including furniture and civil construction, for example.

Another important feature of bamboo-coated battenboard panels is their surface finish. The coloring of the bamboo blades ranges from white to light brown and the orientation of the fiber bundles in the region of the internodes is straight, giving the bamboo-coated panel a uniquely attractive appearance.

\section{CONCLUSIONS}

1. The use of bamboo veneers as a mechanical reinforcement is effective for both eucalyptus wood specimens and edge glued panels;

2. Panels of eucalyptus laths coated with fine bamboo veneers provide a significant mechanical reinforcement and modified behavior at rupture by allowing the panel to bend, making it more elastic, ductile and reliable.

\section{ACKNOWLEDGMENTS}

Especially to Professor Marcos Tadeu Tibúrcio Gonçalves, for the collaboration; Celso Salamon, for the laminated bamboos; Juliano Rodrigo de Brito, for the help in the essays; and to all the good friends at the Universidade Estadual Paulista, Campus Itapeva.

\section{REFERENCES}

AMADA, S. The mechanical structures of bamboos in viewpoint of functionally gradient and composite materials. Journal of Composite Materials, v. 30, n. 7, p. 801-819, 1996.

ASSOCIAÇÃO BRASILEIRADE NORMAS TÉCNICAS (ABNT). NBR 7190: projeto de estruturas de madeira. Rio de Janeiro: ABNT, 1997.

CORTEZ-BARBOSA, J. et al. Materiais lignocelulósicos reforçados com lâminas de bambu. In: DRUMOND, P. M.; WIEDMAN, G. (Orgs.). Bambus no Brasil: da biologia à tecnologia. Rio de Janeiro: ICH, 2017. p. 542-551.

DUNKELBERG, K. Bamboo as a building material. Stuttgart: Karl Krämer Verlag, 1992.
EUROPEAN COMMITTEE FOR STANDARDIZATION (ECS). DIN EN-204: classification of thermoplastic wood adhesives for non-structural applications. Brussels: ECS, 2001.

EUROPEAN COMMITTEE FOR STANDARDIZATION (ECS). NP EN-310: placas de derivados de madeira: determinação do módulo de elasticidade em flexão e da resistência à flexão. Brussels: ECS, 2000.

GHAVAMI, K.; RODRIGUES, C. S.; PACIORNICK, S. Bamboo: functionally graded composite material. Asian Journal of Civil Engineering (Building and Housing), v. 4, n. 1, p. 1-10, 2003.

GONÇALVES, M. T. T. Processamento da madeira. Bauru: USC, 2000.

HSIUNG, W. El bambú en China: nuevas perspectivas para un recurso antiguo. Journal of Forestry and Forest Industries, v. 39, n. 156, p. 88-101, 1987.

IWAKIRI, S. Painéis de madeira: características tecnológicas e aplicações. Revista da Madeira, n. 71, p. 25-33, 2003.

LAHR, F. A. R.; CHRISTOFORO, A. L. (Orgs.). Painéis de partículas de madeira e de materiais lignocelulósicos. São Carlos: EESC/USP, 2013.

LEE, A. W. C.; BAI, X.; BANGI, A. P. Flexural properties of bamboo-reinforced southern pine OSB beams. Forest Products Journal, v. 47, n. 6, p. 74-78, 1997.

MOIZÉS, F. A. Painéis de bambu: uso e aplicações: uma experiência didática nos cursos de design em Bauru. 2007. 113 f. Dissertação (Mestrado em Desenho Industrial) Universidade Estadual Paulista, Bauru, 2007.

OSTAPIV, F. et al. Madeira de bambu como um compósito natural funcionalmente graduado (FGM): propriedades de lâminas torneadas de Phyllostachys pubescens. In: ENCONTRO BRASILEIRO DE MADEIRAS E ESTRUTURAS EM MADEIRA, 12., 2010, Lavras. Anais... Lavras: Ed. UFLa, 2010. 1 CD-ROM.

OSTAPIV, F. Mechanical strength of composite material: eucalyptus wood-bamboo veneer. 2011. $148 \mathrm{f}$. Tese (Doutorado em Engenharia Mecânica) - Universidade Estadual Paulista, Guaratinguetá, 2011.

SALAMON, C. Ensaios para viabilizar a laminação do bambu Dendrocalamus asper em operações de torneamento sem centros. 2009. 114 f. Tese (Doutorado em Engenharia Mecânica) - Universidade Estadual Paulista, Guaratinguetá, 2009.

VIDAURRE, G. et al. Madeira serrada de eucalipto. Revista da Madeira, n. 102, p. 32-38, 2007.

YU, X. Bamboo: structure and culture: utilizing bamboo in the industrial context with reference to its structural and cultural dimensions. 2007. 178 f. Dissertation (Doktors der Philosophie) - Universität Duisburg, Essen, 2007.

ZANG, Q.; JIANG, S.; TANG, Y. Industrial utilization on bamboo. Beijing: INBAR, 2002. 